\title{
The strategic role of the halal study center in supporting halal product assurance policy
}

\author{
H. Pratikto, Y. Agustina*, M. Diantoro \& M. Churiyah \\ Universitas Negeri Malang, Indonesia \\ F.M. Yusof \\ University Technology of Malaysia, Malaysia
}

\begin{abstract}
This study aims to describe the strategic role of Halal Studies Centers in supporting government policies in guaranteeing halal products. The research setting was 7 Halal Center s, the main informant was the head of the university's Halal Center. The data was obtained through indepth review. The research findings indicate that the strategic role of the University's Halal Center is to carry out research on guaranteed halal products that are published to the public, and prepare human resources as halal auditors. The duties of the Halal Supervisor include: supervising the Halal Product Process in the company, determining corrective and preventive actions, coordinating halal product process, assisting the Halal Auditor during the inspection provide assistance to business actors in applying for halal certification, providing recommendations to regulators of halal product assurance, and bringing awareness of halal lifestyle for the community.
\end{abstract}

Keywords: Halal Center, Halal Study, Halal Policy, Guaranteed Halal Products

\section{INTRODUCTION}

The first position as a country with the largest Muslim population in the world is still occupied by Indonesia. The data from 2019 recorded that there were 209.1 million Muslims in Indonesia, or $87.2 \%$ of the total population of Indonesia. This number represents $13.1 \%$ of all Muslims in the world (Pew Forum on Religion \& Public Life 2019). Accordingly, halal products in the form of goods and services are a necessity for the community. This is because Allah SWT affirms in the words of Surah Al-Baqarah verse 168:

"O mankind, eat from whatever is on earth [that is] lawful and good and do not follow the footsteps of Satan. Indeed, he is to you a clear enemy."

In other verse within An-Nahl, verse 114 precisely, it is also affirmed that:

"Then eat of what Allah has provided for you [which is] lawful and good. And be grateful for the favor of Allah, if it is [indeed] Him that you worship."

This is also reinforced by the results of research by Aransyah et al. (2019), which in their research stated that the halal label on a product encompasses a significant effect of Muslim consumers on the decision to buy a product. Aisyah (2016) and Briliana and Mursito (2017), in their research results, also confirm that Indonesians pay great attention to the halal aspects of cosmetic and personal care products to be purchased. In services such as tourism, public awareness of the importance of implementing the halal concept is also increasing, although there are still pros and cons (Jaelani 2017). Through this explanation, the consumption of halal products is a necessity for the Muslim

*Corresponding author 
community in Indonesia. However, the reality is conflicting these days, where there are still Muslim customers who have difficulty identifying whether the products they purchase are halal or vice versa. Tabrany (in Al-Asyhar 2003) emphasized that in Islam, food prohibition is according to the aspect of faith based on applied teachings. Jalil et al. (2018) also stated that healthy and halal foods go hand in hand.

A purified soul is reflected in consuming halal food. The human mind becomes peaceful and tranquil when consuming halal foods (Zannierah Syed Marzuki et al. 2012). On the other hand, there are physical and mental jeopardy contained in foods that are forbidden by the teaching of Islam (Sabry \& Vohra 2013). Halal food has four impacts on human behavior, specifically: a) maintaining the balance of the human soul according to its nature; b) fostering wholeheartedness to uphold and maintain Islamic teachings continually; c) keeping the human mouth open to perpetually saying virtuous words and cleansing the human heart from negative qualities; and d) fostering optimism that God is always with the human being and listens to every prayer. This is based on the hadith narrated by Thabrani from Ibn Abas, precisely:

"You shall righteously eat to make your prayer be granted"

The above explanation indicates that bad human behavior such as corruption, lying, behaving arbitrarily, and so on are caused by the consumption of products that are not halal. For them, there is no relation between whatever is consumed and the dimension of spirituality. PEW Research (2011) in its report predicts that the world's Muslim population will amount to 26.5 percent of the world's population by 2030. In addition, according to the 2019 GMTI report, Muslim tourists in 2020 will spend up to a nominal value of 200 US dollars (Churiyah et al. 2020). Currently, a number of countries, both with a majority Muslim population such as Indonesia, Turkey, and Malaysia as well as countries with Muslim minorities such as Thailand, South Korea, and Japan, are attempting to attract Middle Eastern tourists (Rasul 2019). Indonesia as a country with the largest Muslim population globally, has the potential to develop halal tourism (Churiyah et al. 2020; Jaelani 2017; Suradin 2018). Based on this opportunity, the Indonesian government encourages the development of halal tourism in various regions. The Malang local government also agreed this through the Malang program's launch to develop a halal tourism destination (Hakim 2019; Rifa'i 2019). To accelerate the realization of this program, cooperation is required between universities, the industrial stakeholders, and the government.

The State University of Malang (Universitas Negeri Malang) as a university guarantees the quality of halal products, as indicated by the establishment of the Halal Center (PH) in LP2M (Research and Community Services Agency) in February 2019. This Halal Center, among others, aims at producing research and community service projects in the field of outstanding halal products and realizing a healthy organization with a transparent and accountable governance system. Along with the competence of the $21^{s t}$ century generation, covering four Cs (Critical Thinking and Problem Solving, Creativity and Innovation, Collaboration, Communication) and to strengthen the management of the Halal Center team, it is necessary to conduct a SWOT (Strengths, Weaknesses, Opportunities, and Threats) analysis to determine development strategies and synergize with parties to develop a guaranteed halal products, including the established Higher Education Halal Studies Center, the Halal Product Guarantee Management Agency (BPJPH), the Indonesian Ulema Council (MUI), the business community and the industrial stakeholders, both on a national and international scale.

\section{METHODS}

Based on the existing phenomena, variables related to the development of a halal study center were identified. The findings of these variables were then resorted to as the basis for developing the Halal Center management model. This qualitative approach attempted to answer the objectives of this study. This research was conducted at the Halal Product Guarantee Management Agency (BPJPH), Indonesian Ulema Council (MUI), National and International Universities that have developed the Center for Halal Studies. National Universities which were selected were ITS Surabaya Halal 
Studies Center, IPB Bogor, and ITB Bandung. Meanwhile, the selected international universities are the Technological University of Malaysia under the Ibnu Sina Institute and the University of Chulalongkorn Thailand. Initial research data collection was carried out by in-depth interviews, document archives, participatory observation, and direct observation.

\section{RESULTS AND DISCUSSION}

The general objective of this research is to generate a management model for the halal study center to strengthen the Management of the Halal Center of LP2M State University of Malang. The following are details of the results of this study.

\subsection{The role of university to administer halal product guarantee}

The halal certificate is defined as a recognition issued by the Halal Product Guarantee Agency (BPJPH) based on a written halal fatwa issued by the Indonesian Ulema Council (MUI) to recognize the halal status of a product. Meanwhile, Halal Product Process is a series of activities that include the provision of materials, processing, storage, packaging, distribution, sale, and presentation of products carried out to ensure the product's halal status. Fatwa is given by MUI based on the results of examination and/or examining the halal status of a product. This is carried out by the Halal Inspection Agency (LPH). The implementation of tasks by LPH are supported by a Halal Auditor, specifically parties who have the capability to check the halal status of a product and they have a product halal examination/testing laboratory. Within JPH, business actors are supported by Halal Supervisors who are responsible for PPH.

Based on Figure 1, the role of Higher Education is in the position of the establishment and management of the Halal Center (HC) and LPH. Halal Center (HC) is an institution with the ability to carry out assistance, research and other projects. The Halal Center is assigned to assist MSME. The source of fees is based on the Community Service Fund College; Corporate CSR; and on other independent businesses. HC was established by Government Agencies, Islamic Foundations, State Universities (PTN), and Private Universities (PTS) from Islamic foundations. HC is tasked with assisting, fostering, and supervising Halal Product Assurance, entering the data using the relevant officers (Halal Supervisor) to BPJPH, and managing data (Data Bank). In addition, Figure 1 illustrates the substantial process of Halal Center in carrying out the assistance to MSMEs.

Regarding the Implementation of the Halal Product Guarantee, besides establishing a HC, state universities can establish an LPH. This institution is tasked with checking and testing the halal status of a product. Then, BPJPH issued an LPH accreditation certificate based on the determination of conformity assessment by KAN and MUI. The validity period of the LPH accreditation certificate

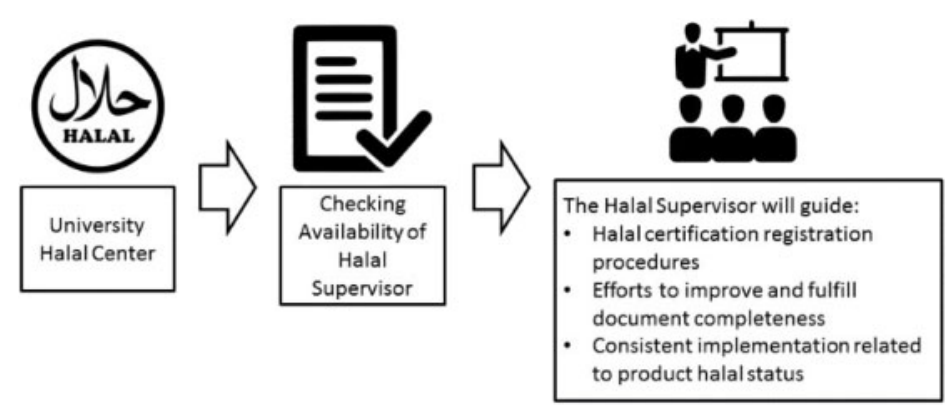

Figure 1. The role model of University Halal Center. 
is five years since it was issued by BPJPH. The existence of Halal Centers in universities plays a role in supporting the halal guarantee policy for the Indonesian government (Akim et al. 2018). In addition, its existence is also an important factor to improve the quality of guaranteed halal products in Indonesia (Gunawan 2020) and an effort to increase the promotion of the halal industry (Yunos et al. 2014). It is expected that the Halal Center in higher education, through its various efforts, can reduce certain public sentiments regarding the concept of halal products (Ainin et al. 2020; Churiyah et al. 2020).

\subsection{Center for Halal Studies}

\subsubsection{Institut Teknologi Sepuluh Nopember (ITS)}

The Center for Halal Studies of ITS, known as ITS Halal Center, was inaugurated in 2016. This Center for Halal Studies is under the ITS Research and Community Services Institution (LP2M). In carrying out its duties, ITS Halal Center always carries out various activities, including education, research, analysis, provision of services to the community, and participating in providing input to the government regarding halal products and regulations. The need for information needed by the public regarding detailed and accurate halal products is the basis for forming the ITS Halal Center institution. Conducting research to find substitutes for haram products commonly used as ingredients for medicines and food is one of the Halal Center's important rol es so far.

\subsubsection{IPB Halal Science Center (HSC IPB)}

Through the provisions contained in the IPB Academic Senate Decree No. 79 / SA-IPB / K / 2017, the Center for Halal Science Studies of IPB (HSC IPB) is one of the centers for science studies at IPB and is under the auspices of the Research and Community Services Agency of IPB. HSC has an essential role in supporting halal inspection and certification, including efforts to develop competent human resources in the field of halal science. This is done to provide benefits to Indonesian and international society.

\subsubsection{ITB Halal Studies Center (PKH-ITB)}

The ITB Halal Studies Center (PKH-ITB) was introduced in 2015, and in its implementation, this institution involved a great number of faculty members from diverse scientific disciplines in the faculties and schools as well as the research centers in ITB. The institutions involved include: a) a School of Life Sciences and Technology (SITH); b) a School of Pharmacy (SF); c) a School of Electrical Engineering and Informatics (STEI); d) an Institute for Research and Community Service (LPPM); e) a Policy Development Agency (SAPPK); f) a Faculty of Mathematics and Natural Sciences (FMIPA); g) a School of Business and Management (SBM); h) a School of Architecture, Planning, and Institute for Innovation and Entrepreneurship Development (LPIK); i) a Tourism Planning and Development Center (P-P2Par); and j) a Nanoscience and Nanotechnology Research Center.

\subsubsection{Halal Science Center (HSC) Chulalongkorn University of Bangkok, Thailand}

The population of Muslims in Thailand is 7 percent of the total population of 66 million. The halal certification initiated in 1949 was solely authorized by the Central Islamic Council of Thailand (CICOT) according to the National Islamic Organization Administration Act 1997. Laboratory tests to facilitate halal authentication and certification in Thailand was first introduced by the Chulalongkorn University Halal Science Center (HSC) in 1999 (Mohd Nawawi et al. 2019). In line with the country's strategy to support the halal affair in Islamic religion in 2004 and Thailand Diamond Halal in 2004, in 2015, HSC-CU aims at achieving its primary vision of being a leader in halal science. This institution is supported by human resources from diverse faculty members of more than 70 people, including 35 professional Muslim scientists possessing more than 150 complete and modern laboratory equipment sets, and a halal inspection agency that obtained ISO 17025:2005 
certification and has received a world award as a Halal Science Institution. The existence of this institution plays a very important role in the development of halal tourism destinations in Thailand (Chanin et al. 2015), as well as in the development of halal products in general.

\subsubsection{University of Technology Malaysia Halal Studies Center}

Malaysia is one of the leading countries of halal producers in the world, both in terms of institutions that play a role in researching halal products (Azhar 2019), halal food, certification and halal tourism (Henderson 2016; Isa et al. 2018), as well as halal products in general (Nik Muhammad et al. 2009). Halal Center of IIS UTM is under the Center of Research for Fiqh Science \& Technology (CFiRST), which plays an important role in the development and improvement of halal studies in Malaysia on many aspects of halal products. This institution has the vision to be the center of excellence in scientific and technological figh investigation.

\subsubsection{LPPOM-MUI NTB}

LPPOM-MUI is located in Lombok NTB. This institution has the responsibility of being the leader of the national and even international halal center, considering that NTB has been determined as one of the best halal tourism destinations in the world (Firdausi et al. 2017). The LPPOM-MUI ITB aims at carrying out several duties, specifically: a) establishing and developing Halal standards; b) carrying out Certification of Food Products, medicines, and cosmetics circulating and consumed by the public; c) conducting halal education and raise public awareness to always consume halal products; and d) providing comprehensive information about the halal status of the product from various aspects. NTB Province is a pilot province for halal awareness community movement. NTB is appointed as one of Indonesia's sharia tourist destinations, and NTB has been awarded as the world's best halal tourist destination.

\subsection{The Readiness of UM to Support Halal Product Guarantee}

To support achieving its goals, PH-UM hires people who have adequate competence in research, halal process assistance, and halal supervision. The potential of UM in supporting the Halal Product Guarantee can be seen from the availability of human resources, buildings and laboratory facilities owned by UM. There are 49 Lecturers in the Biology Department, 47 from the Chemistry Department, 28 in Industrial Engineering, 17 in the Public Health Department. From the Faculty of Economics, the Department of Management comprises 55 lecturers, 49 people majoring in accounting, and 51 lecturers in development economics. Meanwhile, the existence of a UM central laboratory located in the Faculty of Mathematics and Natural Sciences.

\subsection{The Management Model of UM Halal Center}

The Halal Product Guarantee System Management Model, in accordance with the conditions in the State University of Malang, is in the Halal Center under Research and Community Services Agency (LP2M) with the task of conducting research and publishing, mentoring, and educating business actors, and increasing the capabilities of supervisors. Regarding the establishment of the Halal Inspection Agency, the LPH organizational structure consists of the Chancellor (as the supervisor), the Deputy Chancellor (as the steering board), the Chairperson of the Research and Community Services Agency (LP2M) (as the Person in Charge), the Sharia Supervisory Board (as a unit for consultation on halal products according to Islamic sharia), the Head Halal Center (always implementing the LPH activity program), the Central Laboratory Coordinator (as the person in charge of the Laboratory for inspection and product testing in the lab), the Halal Auditor Team (a collection of Halal Auditors as executors of inspection and testing of halal product processes), and Halal Supervisors (as halal product process assistant team). 


\section{CONCLUSION}

The State University of Malang (UM) has a high level of readiness in supporting the Halal Product Guarantee program, which is shown by having a Halal Center supported by adequate human resources and fairly complete laboratory facilities. Likewise, UM has made a MoU with BPJPH and is ready to establish a Halal Inspection Agency that supports the straightforward process of certification of halal products for business actors. The UM Halal Center's existence provides benefits to the Indonesian government and, in particular, to the Malang local government in its efforts to launch halal tourism in Malang. Apart from that, the university also obtains benefits to carry out the three pillars of higher education. Business actors, both SMEs and MSMEs, also benefit from providing halal assurance assistance services and the general public to gain easy access to information on halal products. Further research is important to do in order to measure the level of benefit from the existence of the UM Halal Center for the four subjects.

\section{REFERENCES}

Aisyah, M., 2016. Consumer Demand on Halal Cosmetics and Personal Care Products in Indonesia. Al-Iqtishad J. Islam. Econ. 9. https://doi.org/10.15408/aiq.v9i1.1867

Akim, Dr., Dudy Heryadi, R., Utami Dewi, A., Hermawan, C., 2018. Contribution of Higher Education

Institutions in Supporting Indonesian Halal Product Guarantee Policy 2019, in: Proceedings of the 2nd International Conference on Social and Political Development (ICOSOP 2017). Presented at the 2nd International Conference on Social and Political Development (ICOSOP 2017), Atlantis Press, Medan, Indonesia.

Al-Asyhar, T., 2003. Bahaya makanan haram bagi kesehatan jasmani dan kesucian rohani. Al-Mawardi Prima.

Aransyah, M.F., Furqoniah, F., Abdullah, A.H., 2019. The Review Study of Halal Products and Its Impact on Non-Muslims Purchase Intention. IKONOMIKA 4, 181-198.

Azhar, A., 2019. The Role of Islamic Religious Institutions in Halal Consumerism in Malaysia: A Review. Int. J. Innov. 7, 14.

Briliana, V., Mursito, N., 2017. Exploring antecedents and consequences of Indonesian Muslim youths' attitude towards halal cosmetic products: A case study in Jakarta. Asia Pac. Manag. Rev., Entrepreneurship and Management in Turbulent Global Environment 22, 176-184.

Chanin, O., Sriprasert, P., Rahman, H.A., Don, M.S., 2015. Guidelines on Halal Tourism Management in the Andaman Sea Coast of Thailand. J. Econ. Bus. Manag. 3, 791-794.

Churiyah, M., Pratikto, H., Filianti, Akbar, M.F., 2020. Halal Tourism: Between Economic Opportunities and Social Acceptance. Nusant. Halal J. 1, 11.

Firdausi, I., Marantika, S., Firdaus, Z.N., Sajidah, R., 2017. Lombok: Halal Tourism as a New Indonesia Tourism Strategy.

Gunawan, A., 2020. Strategy to Improve the Quality of Indonesian Industrial Halal through Smart Investment and Education Systems 4.0. KnE Soc. Sci. https://doi.org/10.18502/kss.v4i7.6857

Hakim, R., 2019. A Review on Halal Tourism: an Analysis on the Parameters. J. Ilm. Ekon. Islam 5, 166-172.

Henderson, J.C., 2016. Halal food, certification and halal tourism: Insights from Malaysia and Singapore. Tour. Manag. Perspect. 19, 160-164.

Isa, S.M., Chin, P.N., Mohammad, N.U., 2018. Muslim tourist perceived value: a study on Malaysia Halal tourism. J. Islam. Mark. 9, 402-420.

Jaelani, A., 2017. Halal Tourism Industry in Indonesia: Potential and Prospects. SSRN Electron. J.

Jalil, N.S.A., Tawde, A.V., Zito, S., Sinclair, M., Fryer, C., Idrus, Z., Phillips, C.J.C., 2018. Attitudes of the public towards halal food and associated animal welfare issues in two countries with predominantly Muslim and non-Muslim populations. PLOS ONE 13, e0204094.

Mohd Nawawi, M.S.A., Abu-Hussin, M.F., Faid, M.S., Pauzi, N., Man, S., Mohd Sabri, N., 2019. The emergence of halal food industry in non-Muslim countries: a case study of Thailand. J. Islam. Mark. 11, 917-931.

Nik Muhammad, N.M., Isa, F.M., Kifli, B.C., 2009. Positioning Malaysia as Halal-Hub: Integration Role of Supply Chain Strategy and Halal Assurance System. Asian Soc. Sci. 5, p44.

Pew Forum on Religion \& Public Life, 2019. Religion. Pew Res. Cent. URL https://www.pewre-search.org/ projects/religion/ (accessed 10.4.20).

PEW Research, 2011. Global Muslim Population 2030. 
Rasul, T., 2019. The trends, opportunities and challenges of halal tourism: a systematic literature review. Tour. Recreat. Res. 44, 434-450.

Rifa'i, M.N., 2019. Integrasi Pariwisata Halal di Kota Malang. Falah J. Ekon. Syariah 4, 194.

Sabry, W.M., Vohra, A., 2013. Role of Islam in the management of Psychiatric disorders. Indian J. Psychiatry $55, \mathrm{~S} 205-\mathrm{S} 214$.

Suradin, M., 2018. Halal Tourism Promotion in Indonesia: An Analysis on Official Destination Websites. J. Indones. Tour. Dev. Stud. 6, 143-158.

Yunos, R.M., Mahmood, C.F.C., Mansor, N.H.A., 2014. Understanding Mechanisms to Promote Halal Industry-The Stakeholders' Views. Procedia - Soc. Behav. Sci. 130, 160-166.

Zannierah Syed Marzuki, S., Hall, C.M., Ballantine, P.W., 2012. Restaurant managers' perspectives on halal certification. J. Islam. Mark. 3, 47-58. 